\title{
Edukasi Kandungan Nutrisi dan Aspek Keamanan Kelor pada Kelompok Wanita Tani (KWT) "Sri Rejeki" dan Kelompok Tani Hutan (KTH) Desa Bogo Kecamatan Kapas Kabupaten Bojonegoro
}

\author{
Nikmatul Ikhrom Eka Jayani ${ }^{1 *}$, Karina Citra Rani ${ }^{2}$, Noviaty Kresna Darmasetiawan ${ }^{3}$, \\ Ardhia Deasy Rosita Dewi ${ }^{4}$, Finna Setiawan ${ }^{5}$ \\ ${ }^{1,2,5}$ Fakultas Farmasi, ${ }^{3}$ Program Studi Magister Manajemen, Fakultas Bisnis dan Ekonomika, \\ ${ }^{4}$ FakultasTekno Biologi, Universitas Surabaya- Jl. Kalirungkut, Surabaya-60293 \\ *e-mail corresponding author : nikmatul.ikhrom@staff.ubaya.ac.id
}

\begin{abstract}
ABSTRAK
Produk olahan kelor yang sudah dipasarkan oleh KWT telah mendapatkan sertifikat PIRT oleh DINKES setempat. Informasi produk pada kemasan belum dituliskan batasan penggunaan dalam sehari, serta informasi nilai nutrisinya. Menurut UU RI No. 8 Tahun 1999 tentang Perlindungan Konsumen, konsumen berhak atas keamanan, kenyamanan dan keselamatan dalam mengkonsumsi barang/ jasa. Tujuan kegiatan sosialisasi ini adalah untuk edukasi terkait Kandungan Nutrisi dan Aspek Keamanan Kelor. Edukasi diberikan pada ibu-ibu KWT Srirejeki dan Bapak-bapak anggota KTH yang menggeluti usaha dibidang produk olahan kelor, agar lebih memahami nilai nutrisi dan keamanan produk yang mereka pasarkan. Metode yang digunakan untuk peningkatan pengetahuan dengan pemberian materi terkait topik, yang diberikan dengan metode ceramah interaktif oleh narasumer yang kompeten dibidangnya. Pada kegiatan ini dihasilkan dua modul pelatihan yakni Modul Kandungan Nutrisi Kelor dan Modul Tinjauan Efektivitas dan Keamanan Kelor. Dari hasil penilaian kuesioner menunjukkan tingkat pengetahuan peserta pelatihan meningkat dari nilai rerata 74.44 menjadi 88.61, sedangkan untuk pemahaman terhadap keamanan kelor pengetahuan peserta masih sangat kurang (rerata skor nilai total 37.50) dan di akhir sosialisasi (rerata skor nilai total 69.38).
\end{abstract}

Kata kunci : pelatihan; edukasi; kelor; nutrisi; keamanan

\section{ABSTRACT}

Herbal Products of Moringa oleifera was produced by KWT (Farmer Woman's Group). These product were certified by DINKES (Health Unit Ministry) as PIRT (Pangan Industri Rumah Tangga). These products has been marketed with limited information on the packaging. Based on Indonesian Regulation about Safety Product for Consumen (UU RI No. 8 year 1999), the consumers must be guaranted about safety, comfortability, and security about the product. The Objective of the Education program was to give the right information about the Nutrition Content and Safety Aspect From Moringa Tree. Farmer Women's Group (KWT) "Sri Rejeki" and Farmer Forest Group (KTH) Bogo Village, Kapas Bojonegoro District was the participant of this program. Methods for the Education program was interactive discussion with a competent and expertised

Cara Mengutip : Eka Jayani, N. I., Rani, K. C., Darmasetiawan, N. K., Rosita Dewi, A. D., Setiawan, F., (2020). Edukasi Kandungan Nutrisi dan Aspek Keamanan Kelor pada Kelompok Wanita Tani (KWT) "Sri Rejeki” dan Kelompok Tani Hutan (KTH) Desa Bogo Kecamatan Kapas Kabupaten Bojonegoro. JAST : Jurnal Aplikasi Sains dan Teknologi, 4 (1), 18-25. doi:http://dx.doi.org/10.33366/jast.v4i1.1480 
presenter/ trainer. There were two modul program's book which have been published to improve the knowledge of the partocipant regarding the topics. Result from the questionnaire analysis showed that the knowledge about nutritional content of Moringa oleifera was increased from 77.44 to 88.61 and the knowledge about safety aspect of Moringa oleifera was increased from 37.50 to 69.38.

Keywords : training; education; moringa; nutrition; safety

\section{PENDAHULUAN}

Kelor mengandung nutrisi penting diantaranya asam amino esensial, karbohidrat, mineral sebagai makro elemen (kalsium, magnesium, potassium, fosfor dan sulfur), mineral sebagai mikroelemen (besi, zink, tembaga dan mangan), asam lemak, omega-6, vitamin, klorofil, antioksidan (lutein, karotenoid, zeatin, kuersetin, kaemferol) dan beta sitosterol. Daun merupakan bagian tanaman kelor yang paling tinggi nilai nutrisinya, yakni mengandung protein (19-29\%), serat (16-24\%), lemak, karbohidrat, mineral dan vitamin (A, B1(thiamine), B2 (riboflavin), C dan E) [1].

Melihat potensi nutrisi yang mumpuni untuk memenuhi kecukupan gizi, maka warga desa Bogo Bojonegoro (Kelompok Wanita Tani dan Kelompok Tani Hutan) mengembangkan kelor. Kelompok Wanita Tani (KWT) dan Kelompok Tani Hutan (KTH) Desa Bogo, Kapas, Bojonegoro adalah MITRA dalam kegiatan Pengabdian Masyarakat. MITRA pengabdian merupakan kelompok yang menggeluti usaha dibidang budidaya, pemrosesan panen, pasca panen, pembutan produk sampai dengan penjulan produk berbahan dasar kelor.

Produk olahan kelor yang sudah dipasarkan oleh KWT diantaranya teh celup daun kelor, teh tubruk daun kelor, serbuk daun kelor kering. Produk-produk tersebut telah mendapatkan sertifikat PIRT oleh DINKES setempat. Informasi yang ada pada produk yang dipasarkan terbatas pada cara pemakaian untuk teh celup, yakni 1 teh celup diseduh dengan $150 \mathrm{ml}$ air hangat. Pada kemasan produk belum dituliskan batasan penggunaan dalam sehari, serta informasi nilai nutrisi pada produk tersebut. Menurut UU RI No. 8 Tahun 1999 tentang Perlindungan Konsumen, konsumen berhak atas keamanan, kenyamanan dan keselamatan dalam mengkonsumsi barang/ jasa [2] .

Menyikapi permasalahan tersebut, perlu dilakukan Edukasi terkait Kandungan Nutrisi dan Aspek Keamanan Kelor. Edukasi diberikan pada ibu-ibu KWT Srirejeki dan Bapak-bapak anggota KTH yang menggeluti usaha dibidang produk olahan kelor. Untuk melihat peningkatan pemahaman terkait hal tersebut maka digunakan instrument kuesioner.

\section{METODE KEGIATAN}

Pelatihan terkait kandungan nutrisi kelor dilakukan pada 20 Juni 2019 dan Pelatihan terkait keamanan kelor pada tanggal 8 agustus 2019. Metode yang digunakan untuk peningkatan pengetahuan dengan pemberian materi terkait topik, yang diberikan dengan metode ceramah interaktif.

- Pendidikan Masyarakat

Penyuluhan nutrisi bertujuan untuk meningkatkan pemahaman MITRA 
terkait kandungan nutrisi daun kelor, bagaimana memproses daun kelor segar menjadi produk daun kelor kering (teh celup, serbuk, teh tubruk) yang baik dan benar sehingga kandungan nutrisi di dalam daun kelor tetap terjaga dan pada akhirnya akan didapatkan produk yang terjaga kualitasnya. Selain itu, diharapkan MITRA mampu menuliskan informasi nilai nutrisi pada produk yang dipasarkan sehingga konsumen akan lebih percaya dan meningkatkan nilai acceptability serta safety produk.

Penyuluhan keamanan kelor bertujuan meningkatkan pemahaman MITRA bahwasanya kelor selain kaya akan nutrisi dan nilai kemanfaatan sebagai obat. Harus dipertimbangkan juga aspek keamanan dari pemberian/ penggunaan herbal, sehingga menyadarkan masyarakat akan adanya batasan rentang keamanan pada produk berbahan daun kelor agar tidak menimbulkan efek samping yang tidak diinginkan.

Sebelum pemaparan materi dari narasumber, peserta diberikan pretest terlebih dahulu untuk mengetahui pengetahuan dasar terkait nutrisi dan keamanan kelor. Setelah mengikuti kegiatan pelatihan peserta diminta untuk mengisi post test. Hasil pretest dan post test merupakan skor total dan disajikan dalam bentuk diagram batang .

\section{KARYA UTAMA}

Kegiatan penyuluhan dibagi menjadi dua kali kegiatan.

\subsection{Penyuluhan Kandungan Nutrisi Kelor}

Tim PPDM Sentra Kelor Desa Bogo bekerjasama dengan dosen Fakultas Teknobiologi Universitas Surabaya memberikan sosialisasi kandungan nutrisi kelor. Hal ini diperlukan agar seluruh anggota kelompok tersebut dapat memberikan informasi yang tepat kepada konsumen terkait kelor. Pelatihan ini juga bertujuan untuk memberi masukan dan pertimbangan terkait tahapan proses produksi yang harus dikontrol untuk mendapatkan kandungan nutrisi dan senyawa penting lain yang dibutuhkan oleh tubuh. Pendampingan terkait tahapan proses produksi teh kelor di Desa Bogo telah dilakukan dan menghasilkan SOP (standard Operasional Prosedur) penyiapan simplisia kelor [3].

Tim PPDM Sentra Kelor juga melakukan penyusunan modul mengenai kandungan nutrisi kelor dengan tujuan seluruh anggota kelompok bisa mempelajari kembali materi tersebut setelah pelatihan. Peserta pelatihan berjumlah 18 orang. Modul Kandungan Nutrisi Kelor pada Gambar 1.

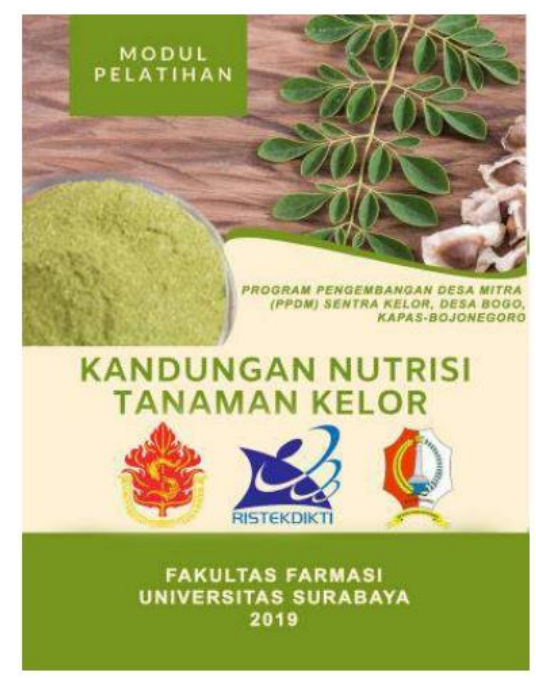

Gambar 1. Modul Kandungan Nutrisi Kelor 
Kelor mengandung fitonutrien dan mempunyai bioaktivitas yang bermanfaat untuk kesehatan. Setiap bagian kelor merupakan sumber nutrien penting. Daun kelor kaya akan mineral seperti kalsium, potasium, zinc, magnesium, besi, dan tembaga. Vitamin seperti betakaroten dari vitamin A, vitamin B seperti asam folat, vitamin $\mathrm{C}$, vitamin $\mathrm{D}$, dan vitamin $\mathrm{E}$. Daun kelor segar merupakan sumber karotenoid seperti trans-lutein (sekitar 37 $\mathrm{mg} / 100 \mathrm{~g}$ ), trans- $\beta$-karoten (sekitar 18 $\mathrm{mg} / 100 \mathrm{~g}$ ) dan trans-zeaxanthin (sekitar 6 $\mathrm{mg} / 100 \mathrm{~g}$ ) [4]. Dari hasil penelitian yang dilakukan oleh Jayani et al tentang standarisasi daun kelor yang dibudidayakan di Desa Bogo Bojonegoro menunjukkan bahwa simplisia daun kelor memenuhi standard mutu yang tertera pada Farmakope Indonesi edisi II [5]. Sedangkan uji kandungan nutrisi pada serbuk teh kelor yang dilakukan pada lab pengujian menunjukkan kandungan nutrisi daun kelor dari Bogo mengandung karbohidrat $37,89 \%$, protein $26,51 \%$, lemak $8,39 \%$, serat kasar $7,61 \%$, abu 10,96\%, kelembapan 8,64\%, dan kalori total $333,11 \mathrm{Kcal} / 100 \mathrm{~g}$ sampel serbuk daun [6].

Dari hasil studi pustaka menunjukkan bahwa kandungan protein dan lemak pada biji kelor tertinggi $(35.97 \pm 0.19 \mathrm{~g}) / 100 \mathrm{~g}$ dan $(38.67 \pm 0.03$ g)/100 g diikuti daun kering, bubuk daun, daun segar dan polong segar. Kandungan serat bubuk daun kelor memiliki kandungan serat tertinggi (19.2 g/ $100 \mathrm{~g})$. Kandungan vitamin B kompleks tertinggi pada bubuk daun, vitamin $\mathrm{C}$ tertinggi pada daun segar dan vitamin E pada biji kelor [7]. Foto kegiatan dan peserta pelatihan dapat dilihat pada gambar 2 .

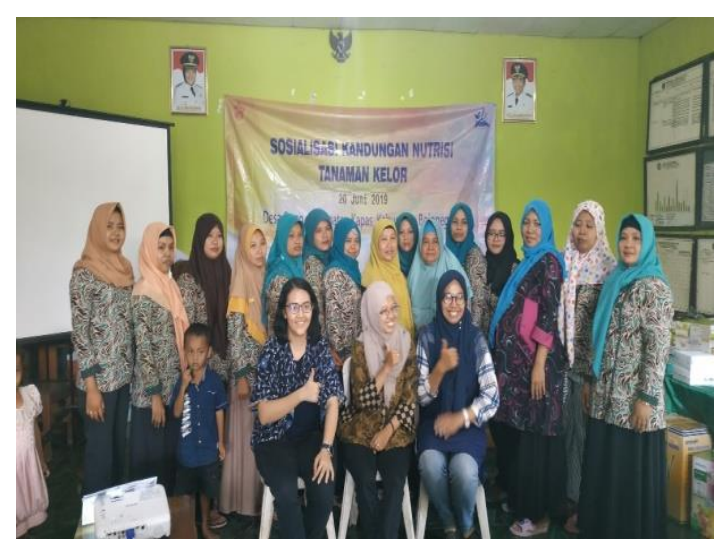

Gambar 2. Foto bersama narasumber "Sosialisasi Kandungan Nutrisi pada Kelor"

Untuk melihat pemahaman MITRA terhadap kandungan nutrisi pada daun kelor dilakukan uji pengetahuan dengan instrument kuesioner. Hasil kuesioner menunjukkan tingkat pengetahuan peserta pelatihan meningkat dari nilai rerata 74.44 menjadi 88.61 (Gambar 3). Dari hasil test menunjukkan bahwa sebenarnya pengetahuan terkait nutrisi pada kelor sudah baik. Setelah pelatihan peserta semakin memahami apa yang disampaikan oleh narasumber. Selain informasi nilai nutrisi pada pangan berbasis kelor juga disampaikan berbagai produk olahan pangan berbasis kelor yang dapat dikembangkan oleh KWT sebagai bentuk diversifikasi produk olahan.

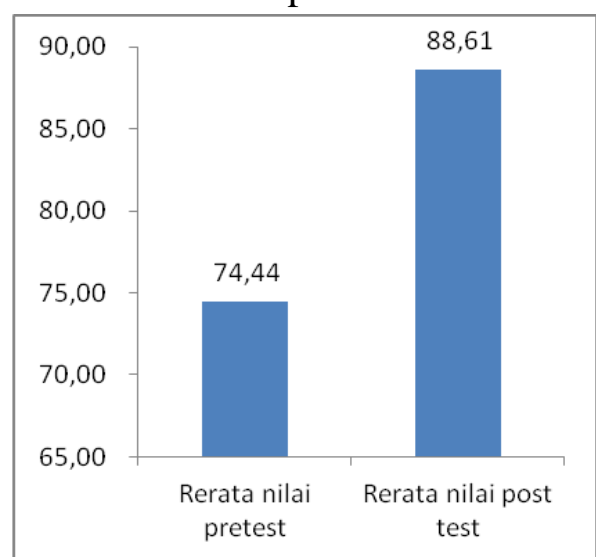

Gambar 3 Kuesioner Tingkat Pengetahuan Nutrisi pada Kelor 


\subsection{Penyuluhan Aspek Keamanan Kelor}

Permasalahan yang ada di konsumen yang mengkonsumsi herbal adalah anggapan jika "natural" selalu diartikan "aman", padahal ada beberapa tanaman yang memang jelas memiliki kandungan racun. Beberapa efek samping yang dilaporkan terkait dengan kualitas dari herbal yang belum terstandart, adanya laporan pemalsuan/ penggantian herbal dengan herbal yang mirip atau ditambahkannya Bahan kimia obat pada produk obat herbal.

Faktor-faktor lain yang bisa menimbulkan efek samping herbal diantaranya kesalahan spesies karena tanamannya "mirip", kesalahan pengambilan bagian tanaman yang berkhasiat, dosis yang tidak tepat, "error" dalam penyiapan/ penggunaan herbal, adanya ninteraksi herbal dengan herbal, dengan obat sintetik dengan makanan, produk herbal terkontaminasi dengan kontaminan (mikrobiologi, loham berat, residu pestisida) dan adanya perhatian penggunaan herbal pada usia atau kondisi khusus tertentu (anak, lansia, pasien gangguan hepar, gangguan ginjal, ibu hamil, ibu menyusui)[8].

Aspek keamanan yang akan diulas pada penyuluhan ini terutama terkait dosis pemakaian, resiko munculnya efek samping teh kelor serta cara mengkonsumsi teh kelor yang benar. Pentingnya penyuluhan terkait keamanan herbal dalam hal ini khususnya teh kelor adalah karena dari hasil penelitian konsumen beranggapan bahwa obat herbal dapat menyembuhkan semua penyakit, lebih manjur, lebih murah, lebih aman dibandingkan obat sintetik. Dari penelitian yang sama juga dilaporkan munculnya efek samping yang tidak diinginkan terkait herbalyanki mual, perut sebah, muka dan wajah bengkak, urine menjadi gelap dan sakit kepala [9].

Pada kegiatan Sosisalisai Keamanan kelor disediakan Modul terkait topik (gambar 4).

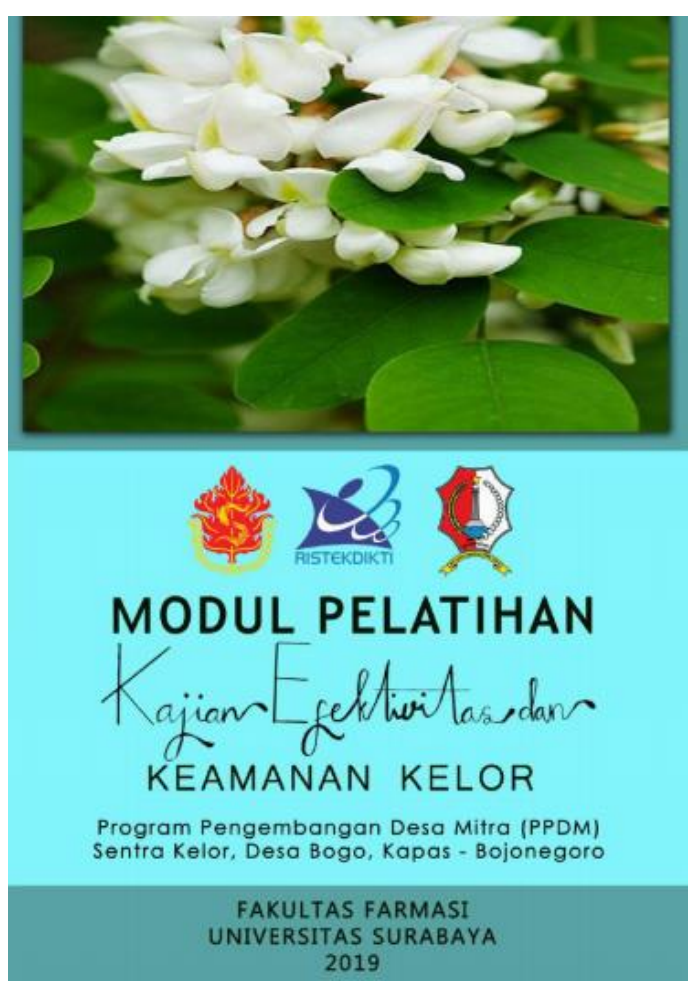

Gambar 4. Modul Kajian Efektivitas dan Keamanan Kelor

Salah satu pertanyaan kepada peserta adalah apakah ada yang mengkonsumsi seduhan teh/ serbuk daun kelor setiap hari, dan berapa dosis yang digunakan. Salah seorang peserta (Wanita, 45 tahun) menyebutkan bahwasanya rutin mengkonsumsi kelor untuk mengontrol gula darahnya yang cukup tinggi. Dosis yang digunakan adalah tiga kali satu sendok serbuk kelor yang diseduh pada segelas air panas. Setelah dilakukan penggalian ternyata yang bersangkutan mengalami efek samping frekuensi 
berkemih yang sering terutama di malam hari sehingga mengganggu waktu tidurnya. Penelitian yang dilakukan Tahkur (2016) mengenai pemberian ekstrak etanol daun kelor pada tikus menunjukkan efek diuretik yang signifikan, semakin meningkat dosis semakian meningkat efek diuretic. Efek diuretic kelor lebih rendah dibandingkan dengan obat diuretic Hidroklorthiazid [10].

Penjelasan keamanan dan efektifitas mengulas berbagai hasil penelitian terkait keamanan setiap bagian dari kelor. Narasumber juga memberikan penjelasan terkait dengan jumlah atau dosis setiap bagian kelor yang aman digunakan. Kajian keamanan kelor pada tikus yang diberikan infus daun kelor secara per oral pada dosis 400, 800, 1600 dan 2000 $\mathrm{mg} / \mathrm{kg}$ BB dilakukan oleh Adedapo et al (2009). Kelor diberikan dalam dosis tunggal selama 21 hari terapi. Beberapa parameter yang diukur termasuk profil hematologis dan serum enzim yang menunjukkan bahwa infus daun kelor aman sampai pada dosis $2000 \mathrm{mg} / \mathrm{kgBB}$ [11]. Efek toksik yang potensial dari pemberian dosis tunggal ekstrak air daun kelor 1000-5000 mg/kgBB selama 14 hari pada tikus menunjukkan tidak ditemukan efek samping pada dosis yang diberikan, pemeriksaan histopatologi baik namun serum enzim hati meningkat sesuai peningkatan dosis [12].

Adanya laporan efek samping kelor diantaranya angioedema, anaphylaxis shock pada pasien yang mengkonsumsi biji kelor muda dan adanya kasus pankretitis dan fixed drug eruption pada pasien yang mengkonsumsi daun kelor [13],[14],[15]. Diskusi interaktif juga dilakukan oleh narasumber kepada peserta sosialisasi mengenai penggunaan daun dan biji kelor yang selama ini dilakukan. Berdasarkan hasil diskusi tersebut diketahui bahwa penggunaan kelor oleh masyarakat Desa Bogo masih berada dalam tahap aman. Narasumber juga memamaparkan bahwa penggunaan setiap bagian kelor harus tetap memperhatikan dosis, karena penggunaan yang berlebihan dapat memicu kerusakan ginjal, liver, otak, dan menimbulkan masalah pada kulit. Gambar 5 menunjukkan kegiatan sosialisasi keamanan kelor.

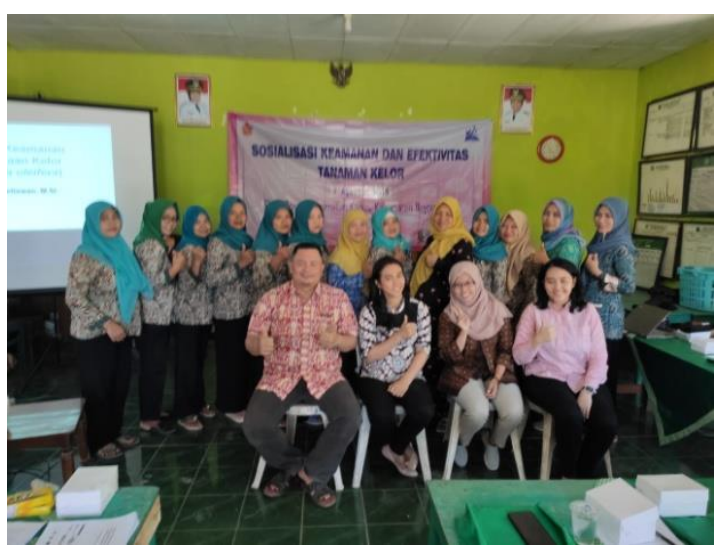

Gambar 5. Peserta Sosialisasi bersama dengan Narasumber

Dari Kegiatan penyuluhan dengan topik keamanan kelor ini diharapkan dalam penyiapan produk teh kelor, MITRA memahami pentingnya menyediakan produk yang aman bagi konsumen. Selain itu MITRA diharapkan mampu memahami banyak aspek yang mempengaruhi keamanan dari suatu produk herbal. Tingkat pengetahuan peserta sosialisasi diukur dengan memberikan kuesioner terkait topik keamanan kelor sebelum dan sesudah pemaparan materi. Gambar 6 menunjukkan hasil kuesioner pemahaman peserta. 


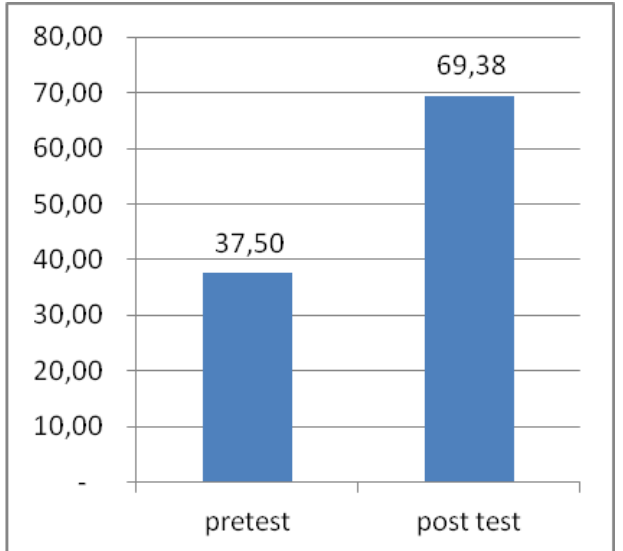

Gambar 6 Kuesioner Tingkat Pengetahuan Keamanan Kelor

Dari hasil keusioner pada gambar 6 dapat dilihat bahwa pengetahuan peserta masih sangat kurang terkait keamanan kelor (rerata skor nilai total 37.50) dan meningkat di akhir sosialisasi (rerata skor nilai total 69.38). Secara umum peserta belum paham dengan dosis/ takaran dan masih memiliki pendapata umum bahwasanya herbal tanpa efek samping dan aman untuk dikonsumsi.

\section{ULASAN KARYA}

Kegiatan dan program sosialisasi yang dilakukan menunjukkan respon positif pada peningkatan tingkat pengetahuan anggota KWT dan KTH yang mengikuti kegiatan. Peningkatan pengetahuan ini diperlukan karena KWT dan KTH memasarkan produk herbal (teh celup, teh tubruk, serbuk daun kelor) yang harus dijaminkan kualitas dan keamannya untuk konsumen. Penyediaan Modul terkait kandungan nutrisi dan modul terkait efektivitas dan keamanan kelor diharapkan dapat memberikan wawasan yang lebih komprehensif dan dapat dibaca kembali oleh anggota KWT dan KTH untuk meningkatkan pemahamannya.

\section{DAMPAK DAN MANFAAT KEGIATAN}

Kedepannya diharpkan akan ada perbaikan pada kemasan produk yang wajib dituliskan cara penggunaan dan dosis / takaran penggunaan nya. Sehinnga produk yang telah dipasarkan lebih terjamin keamanannya. TIM pengabdian juga akan bekerjasama dengan DINKES setempat terkait sosialiasi dalam menjaga kualitas produk yang telah mendapatkan sertifikasi PIRT.

\section{KESIMPULAN}

Setelah dilakukan sosialisasi terkait kandungan nutrisi dan aspek keamanan kelor dapat disimpulkan bahwa terjadi peningkatan pengetahuan peserta sosialisai ditunjukkan dengan skor total kuesioner yang meningtat pada post test dibandingkan dengan pretest.

\section{PENGHARGAAN}

PPDM Sentra Kelor Desa Bogo Kecamatan Kapas Bojonegoro dibiayai oleh : Direktorat Riset dan Pengabdian Masyarakat Direktorat Jendral Penguatan Riset Pengembangan Kementrian Riset, Teknologi dan Pendidikan Tinggi sesuai dengan Kontrak Pengabdian Kepada Masyarakat Nomor:005/SPP-PPM/LPPM02/DRPM/FF/III/2019

\section{DAFTAR PUSTAKA}

[1] Rani KC, Nani P, Pragita P, Elisabeth R. 2019. Pengembangan Nutrasetikal Sereal Daun Kelor (Moringa oleifera L.) dengan Tepung Garut (Maranta arundinaceae L.) sebagai pengikat. Jurnal Farmasi Indonesia. Vol 11 No 2: $38-50$ 
[2] Undang-undang Republik Indonesia No 8 Tahun 1999 tentang Perlindungan Konsumen

[3] Parfati N, Karina CR, Nikmatul IEJ. 2018. Pemberdayaan Kelompok Wanita Tani dalam Perbaikan Proses Produksi Olahan Berbasis Kelor di Desa Bogo, Kecamatan Kapas, Bojonegoro. Unes Journal of Community Service Vol 3 issue 2: 226236

[4] Chinwe I, Jose SM, Jaramillo J, Fausto D. 2013. Phytochemical and Nutritional Properties of Dried Leaf Powder of Moringa oleifera Lam. from Machala El Oro Province of Ecuador.1:5454.

[5] Jayani, NIE., Kartini., Putri, LK. 2020. Standardization of a Crude Drug Moringa oleifera Leaf from Africa, India and Local (Indonesian) which Cultivated in Bojonegoro Indonesia, International Journal of Pharmaceutical Research. 12 (2).

[6] Sucofindo Laboratory. 2019. Report of Proximate Analysis Serbuk Daun Kelor Bogo.

[7] Gopalakrishnan L, Doriya K, Kumar DS. 2016. Moringa oleifera: A review on nutritive importance and its medicinal application. Food Sci Hum Wellness.5(2):49-56.

[8] WHO, 2004. WHO Guidelines on Safety Monitoring of Herbal Medicines in Pharmacovigilance Systems. Geneva

[9] Gitawati, Retno, Rini SH. 2008. Profil Konsumen Obat Tradisional terhadap Ketanggapan akan adanya Efek
Samping Obat Tradisional. Buletin Penelitian Sistem Kesehatan-Vol 11 No 3

[10] Tahkur R S., Geeta S., Rama M P., Madhavulu B., 2016. Diuretic Activity of Moringa oleifera Leaves Extract in Swiss Albino Rats. The Pharma Innovation Journal; 593): 08-10

[11] Adedapo AA, Mogbojuri OM, Emikpe BO. 2009. Safety evaluations of the aqueous extract of the leaves of Moringa oleifera in rats. Journal of Medicinal Plants Research;3(8)586591.

[12] Asiedu-Gyekye IJ. S FrimpongManso. C Awortwe. D A Antwi dan A K Nyarko. 2014. Micro- and Macroelemental Composition and Safety Evaluation of the Nutraceutical Moringa oleifera Leaves. Hidawi Publishing Corporation Journal of Toxicology. vol 2014: 1-13

[13] Lee, Rim. Seong A. Sang Y H. Cheon K. dan Joon T K. 2015. Acute Pancreatitis Induced by Moringa oleifera in a 48 years Old Korean Women : A Case Report. Toxicology. Vol 26 No 6: 612-615

[14] Olanrewaju FO. Olaniyl O. Olayinka AO. dan Muphy MO. 2017. Fixed Drug Eruption induced by Moringa oleifera Leaf Extracts - A Case Report. Our Dermatol Online, no 4: 413-416

[15] Berglund L.J. 2018. Anaphylaxis to Moringa oleifera : First description. Australasian Medical Journal, ; 11(3):176-177 